\title{
An Analysis of Chinese Art Market Mechanism with Supply-side Structural Reform
}

\author{
Jie Li \\ Faculty of Economics and Management \\ Communication University of China \\ Beijing, China
}

\begin{abstract}
Chinese art market has become the third largest art market in the world. The size of the art market has gradually grown during the past 30 years, and the total turnover has increased year by year. In recent years, with the weak development of the real economy, art market has entered the period of adjustment and needs to seek the new direction. However, the size of the Chinese art market is shrinking. And the demand of the art market is gradually reduced due to different factors. The development of the whole art market has many problems. The conception of "supply-side reform" just provides a new way for the development of art market. To solve the problems in the supply side of the art market not only has an important influence on the establishment of the price mechanism, but also can ensure the normal and reasonable development of the entire art market.
\end{abstract}

Keywords—supply-side reform; Chinese art market; market mechanism; price mechanism

\section{INTRODUCTION}

It can be seen from the modern history of the art market that the relationship between the development of art market and the real economy is becoming increasingly close. In particular, the period of the prosperity and decline in art market coincided with the rapid development and recession of economy in twenty-first century. For example, the art market showed a clear downward trend during the financial crisis in 2008 , the art price once cut down by $50 \%$. On the micro level, with the rapid growth of national income, the spending on the purchase of art has increased. In addition, people begin to view art as a kind of investment assets like real estate and stock, and the demand for art collection and investment has increased correspondingly.

The operation of art market, especially the price of art, is the result of interaction between supply and demand. One of the most important features of the art market is that its development is affected by supply. No matter how much the price of art has changed, the supply of art is fixed. And it is impossible to have excess supply to meet the increasing demand. Therefore, it is significant to regulate and adjust the supply side of the art market for establishing a reasonable price mechanism and promote the healthy development of the art market.

\section{THE SIGNIFICANCE OF SUPPLY-SIDE REFORM IN CHINESE ART MARKET}

As the representative of the emerging economies in the world, Chinese art market has developed rapidly over the past three decades. In 2011, the turnover of Chinese art market once surpassed the United States, ranking first in the world. According to "Chinese Art Market Annual Report 2011" published by the Ministry of Culture, the total volume of Chinese art market turnover was 210.8 billion yuan with the annual growth rate of $24 \%$. In recent years, with the continuous adjustment of the domestic economy, Chinese art market has developed slowly. Although the size of the art market is shrinking, the development of its art market cannot be underestimated. "TEFAF Art Market Report 2017" shows that the sales of Chinese art market in 2016 were 6.33 billion dollars and remained the third art market in the world with a $18 \%$ market share.

As one of the most important parts of the cultural industry, the rapid development of Chinese art market is closely related to the economic development of our country. As China's economic development has entered "the new normal", the period when the barbaric development of Chinese art market mainly relied on the rapid growth of traditional resources and sharp appreciation of art assets in short term has ended. The whole art industry develops into the period of adjustment. Meanwhile, the further promotion of anti-corruption work in China affects the gift market. The irrational demand in the art market gradually decreases, and the demand side of the entire art market reduces. Many art investors exit the art market, and the number of art buyers is also reduced. What's more, their purchase options have changed and inclined to buy the works of art which have great appreciation spaces and real valuable. Thus, it creates a lot of artworks which have sky-high prices. For example, Huang Binhong's "Huangshan Tangkou", listed at China Guardian Auctions in 2017, had the hammer price with 345 million yuan.

The change of the demand side in art market inevitably affects its supply side. Because the demand of art market continues to decline, the inventories in supply side are excessive. And many sellers tend to retain the works of art during the period of adjustment in art market. Thus, the number of high-quality artworks in art auction market is rare. 
Many small auction houses have to cancel the auction due to the lack of lots. In addition, the domestic collectors began to collect western artworks oversea at a high price, which also reflected the shortage of the supply in Chinese art market. The problem of the supply side in art market should affect the development of the whole market. In November 2015, the central leading group on financial and economic affairs put forwards the concept of "supply-side structural reform". It provides ideas, directions and new opportunities for the development of art market.

\section{The SuPPly-SIDE PROBleMS OF ChINESE ART MARKET MECHANISM}

The supply-side problems of Chinese art market mechanism are mainly reflected in its price mechanism. In the past, the development of Chinese art market was relatively extensive and had serious art pricing bubble problems. Moreover, it is influenced by the demand of gift market that most of the artworks in circulation cannot meet the demand of the market and do not have the value of collection and investment. As mentioned in the introduction, the price of art is the result of the interaction between supply and demand and follows a certain "price law". However, the supply-side problems of art market cause an unsound art pricing mechanism, which influences the establishment of the art price mechanism. The main sources of art market supply are artists and intermediaries such as auction houses, galleries, agents, etc. The following will discuss the problems of the price mechanism in art market from these two main supply sides.

\section{A. Overpriced Artwork Results in the Excessive Inventories}

There are two reasons for the overstocking of artwork. One is the reduction of the market demand. The art supplies are fixed and limited. If the demand for artwork continues to decrease, the supply will be relatively excessive. Another is that the artwork cannot be sold due to its unreasonable pricing. The price of the art is too high, even beyond the purchasing power of some collectors and investors, to curb their potential purchase and collection needs.

There are two cases that the pricing of art is too high. One is that the real prices of artwork are too high. The high price of such artworks was formed in the past when the development of market transactions was overheated. As the size and demand of art market decreased, their price did not decline with the change of market supply and demand and still kept the original high price. The other is that the artists, the upstream of the industrial chain in art market, are accustomed to mark their works at unrealistically high prices due to a matter of pride or other reasons. In fact, their works have not reach such a high price in the market. These two cases have demonstrated that the over-priced artworks are not suitable for the current development of art market. On the contrary, the art sale has been held up and the artworks have a large number of backlog.

\section{B. The Inverted Market Structure Causes the Unsound Price System}

Art price system is based on the structure of the art market. Only a sound market structure can make sure the normal operation of the art price system. A great art market structure should have a clear boundary between the primary market and the secondary market. Each market strictly abides the market rules and actively plays its role. The primary market which is represented by the galleries is to discover and cultivate new artists and also sells the artists' works. It mainly provides a reasonable price standard of the new artworks for the art market. The works of art which only achieve a certain artistic value in primary market can be allowed into the secondary market represented by the auction houses. In this market, the fine art can establish the standard of its market circulation price through auction. Thus, the interaction between the first market and the secondary market affects the formation of the price mechanism in the art market.

At present, the structure of Chinese art market is unsound. The boundary of two markets is blurred, and the division of labor is not clear. The rules of the market are not completely established. Because of the lack of integrity in the market, artists often sell works by themselves or directly participate in the auction of the secondary market. The role of the primary market is not obvious. The galleries only focus on the short-term profits and are reluctant to spend a lot of time and effort to explore and cultivate artists. While the auction houses in secondary market play the role like some galleries and sell the works of emerging artists directly. Furthermore, the market exists the phenomena such as "fake auction", money laundering and so on and have the problems about the increase of operating costs like rent and labor cost. In brief, it cannot form a great price system between primary market and secondary market.

\section{ThreE WAYS OF SOLVING THE PROBLEMS OF} CHINESE ART MARKET MECHANISM FROM THE SUPPLY SIDE

Through the analysis of supply side in Chinese art market, we can find that the establishment of a great price mechanism in art market must solve the issues in the supply side of the art market to ensure the orderly development of the art market.

\section{A. The Destocking of the Art Market}

Now, Chinese art market is in a period of adjustment, and its development is relatively slow. The buyers in the art market are changing, and the interest and demand of new buyers for art are different from the traditional buyers. In such a changeable market environment, artists and art intermediaries must destock in order to solve the problem of excess inventory in Chinese art market, especially the highpriced artworks. They can try to reduce the inventory of artworks by lowering prices and changing marketing strategies, etc. It not only avoids the risk of price collapse during the period of decline in the art market, but also keeps the liquidity which is required for the development of the art market. Meanwhile, it helps the artists to achieve the value of 
their artworks as soon as possible and gain more money for the new artistic creation.

\section{B. Formulation and Improvemrnt of the Relevant Policies and Regulations in the Art Market}

The development of art market in China is very chaotic. The role of the two markets is inverted, and the phenomenon of fake and fraud happens frequently. The most fundamental solution of these problems is to rely on the policies and regulations which are formulated and improved by the government to ensure that the development of all aspects in art market can have the laws to go by. And the laws must be observed. Meanwhile, the management and supervision of the government for the art market in practice need to ensure that the laws and regulations must be strictly enforced, and those who violate the laws must be prosecuted. Therefore, the non-standard phenomena and behavior of the art market can be restricted and stopped to keep the normal development of the art market. In addition, it is necessary to improve the internal self-discipline to constraint its behavior by formulating and improving the norm of the art industry.

\section{Establishment of a Reasonable Pricing Mechanism for Artworks}

The fact that over-priced artworks cause their excess inventory also shows that the pricing mechanism of the art market is not great. At present, there are a variety of pricing standards in Chinese art market. And there is no unified and interrelated pricing system among the artists, galleries and auction houses. They just mark the art sale price of the art according to their own different conditions. Besides, the information between buyers and sellers in art market is asymmetry. The related information of art which the buyers can obtain is very limited, such as origin, authenticity and material, etc., so the sellers can take this opportunity to use various means to speculate and manipulate the art prices in order to influence the judgement of the buyers for the real value of the art. Therefore, it is very important for the development of art market to improve the level of information transparency and establish a good art pricing mechanism.

\section{CONCLUSION}

It has a very important influence on Chinese art market to solve the problems of the market supply-side through the supply-side reform. The supply-side reform of the art market mechanism especially about the price mechanism not only combines with the adjustment period of the art market to promote the development of the art market towards the normal and rational direction, but also benefits to establish the art price system in accordance with the supply and demand of the market, reduce the price bubble phenomenon and make the art market return to its normal operating mechanism. At the same time, the supply-side reform can help the collectors and investors to find the artworks which have the real value of collection and investment. In short, the supply-side reform plays an important role for the future of Chinese art market.

\section{REFERENCES}

[1] Clare McAndrew, Fine Art and High Finance, New York: Bloomberg Press, 2010.

[2] James Goodwin, The International Art Markets, Beijing: China Railway Publishing House, 2010.

[3] Zhong Jinggan, "The 'supply side' of the art market,"Shanghai: Oriental Morning Post,2016.

[4] Feng Shanshu, "The art market is also waiting for a 'supply-side reform','Guangzhou: Collection Auction, 2016.

[5] Fang Xiang, "Supply-side reform"may have new dark horse, Guangzhou:21st Century Business Herald, 2016.

[6] AMMA, Artprice, The Art Market in 2016, unpublished.

[7] TEFAF, TEFAF Art Market Report 2017, unpublished. 